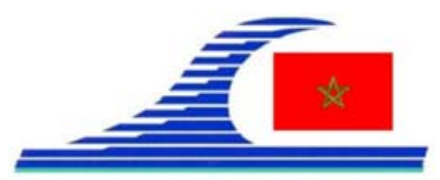

Conférence Méditerranéenne Côtière et Maritime EDITION 2, TANGER, MAROC (2011)

Coastal and Maritime Mediterranean Conference

Disponible en ligne - http://www.paralia.fr - Available online

\title{
The malacological fauna of bivalve seashells of the Mediterranean coast of Morocco
}

\author{
Khalid EL BEKKAYE ${ }^{1}$, Mohammed MELHAOUI ${ }^{1}$ \\ 1. Mohamed First University, Laboratory of Hydrobiology and General Ecology, \\ Faculty of Science, Oujda, Morocco. \\ khalid_elbekkaye@hotmail.fr ; melhaouimohammed@yahoo.fr
}

\begin{abstract}
:
This work is a contribution to the knowledge of the bivalve fauna of the coastal zones in Moroccan Mediterranean Sea. It presents the biological variety of the bivalve Mollusks from the Kiss River in Saidia beach to Sfiha beach in Al Hoceima city.

The systematic determinations allowed us to establish a first exhaustive inventory of the biodiversity of bivalves in these coastal housing environments and their specific wealth. Forty-six species belonging to 20 families were described and mapped in a catalog. Different habitats have been diagnosed as threats to malacological fauna together with the impact of artisanal fishing pressure on some bivalves of economic interest.
\end{abstract}

Key Words: Biodiversity - Bivalve - Mediterranean Sea - Morocco

\section{Introduction}

Thanks to its geographical situation and its paleontological story, the Moroccan coast (MATEE, 2006) is endowed with a big variety of ecosystems as well as botanical and animal species, with a remarkable biological wealth. Besides its socioeconomic interest (MATEE, 1999), the biodiversity of Morocco displays a particular ecological importance. The rarity of works and documents and of specific syntheses on the malacological fauna of the Moroccan Mediterranean Sea (SHAFEE, 1999) induced us to carry out some researches on bivalves lamellibranches of the coastal zones from the Moroccan Algerian border up to the beach of Sfiha of Al Hoceima on a coastal shelf spaced $300 \mathrm{~km}$ with variable-size sand, rocks and gravel in the sampling site (FOUCAULT \& RAOULT, 2005).

\section{Presentation of the research background}

Morocco represents a real crossroads between Europe and Africa, and between the Mediterranean Sea and the Atlantic Ocean. This zone belongs to the sea of Alboran (LLORIS \& RUCABADO, 1998) with temperatures of the sea water which reach maximums of 24 to $25^{\circ} \mathrm{C}$ in summer, and minimal values of 14 to $15^{\circ} \mathrm{C}$ in winters, and a salinity level of 38,5 g/l.

The Mediterranean coast of oriental Morocco is approximately $512 \mathrm{~km}$ long and represents a very important patrimonial value with its natural diversity (LAOUINA, 
La connaissance de la Mer :

un vecteur du développement durable en Méditerranée

2006), panoramic views and biological diversity in halieutic and floral resources that make it a region with increased ecological, economic and landscape interest.

- Sector I: The Saidia beach from the Moroccan Algerian border neighbouring Oued Kiss (IRZI, 2002) up to the new tourism station at the right bank of Moulouya estuary. It is a sandy coast 10 kilometres long.

- Sector II: The water stream from the left bank of the mouth of Moulouya up to Ras Kebdana beach. It is a sandy zone of 4 kilometres, sheltered by the cliffs of Akemkoum el Baz.

- Sector III: From the beach of Kariat Arkman up to the beach of Boukana in Béni Ensar.

- Sector IV: Al Hoceima from Souani up to the beach of Sfiha. It is a sandy and rocky zone of more than $2 \mathrm{~km}$.

\section{Materials and methods}

- Harvests of the bivalves in tide marks and in zones of cleaning of crafts fishing nets.

- Harvests of the bivalves made on the sandy beaches by fishing from the shore.

- Harvests by rakes aboard the boats of fishermen.

- Harvests of the species fixed to the rocks of the coast.

The systematic determinations were realized by means of specialized works (CLANZID, 1989; SAUBADE, 1979). This allowed us to establish a first exhaustive inventory of the biodiversity of bivalves in these coastal housing environments and their specific wealth.

\section{Results and discussions}

The various samples were identified by species and by families, described and mapped in a catalog. The study revealed the presence of threatened and rare species, or presenting an economic or biological interest. (EL BEKKAYE \& MELHAOUI, 2010)

The harvest was carried out during four seasons in the year to obtain a maximum of species which disappear during the period of growth and reproduction. This study also allowed us to list the most exploited species of bivalves by small-scale fishing with the aim of spot marketing. The results presented below bring to light twenty families of bivalves, containing thirty-three kinds and approximately forty-six species.

The sampling revealed the presence of five families of bivalves with economic interest, for instance, Cardiidae, Glycymeridae, Donacidae, Mytilidae and Veneridae (SHAFEE, 1999). The wealth and abundance of bivalves used as indicators of biodiversity have a double quantitative and qualitative purpose, namely the study of the biodiversity of the region which enabled us to determine for example the dominance of a family, the disappearance or the appearance of the species in certain zones, as well as the most threatened species due to excessive exploitation such as: small clams, right knife, hulls, varnish, sea beans, sea almonds and sea dates. 
Table 1. Distribution of families by different collection area.

\begin{tabular}{lcccccc}
\hline \multirow{2}{*}{ Bivalve family } & \multicolumn{4}{c}{ Abundance by site of collection } & Number of species \\
\cline { 2 - 5 } & Site $\mathbf{1}$ & Site 2 & Site 3 & Site $\mathbf{n}$ & per family \\
\hline Anomiidae & ++ & + & + & + & 1 \\
Arcidae & + & + & ++ & ++ & 2 \\
Cardiidae & +++ & +++ & ++ & +++ & 6 \\
Donacidae & ++++ & ++++ & ++ & +++ & 2 \\
Glycymeridae & +++ & +++ & ++++ & ++ & 2 \\
Limidae & + & + & + & + & 2 \\
Mactridae & ++ & ++ & + & +++ & 4 \\
Mytilidae & ++ & ++ & ++ & +++ & 4 \\
Ostreidae & ++ & + & - & - & 2 \\
Pandoridae & + & - & - & + & 1 \\
Pectinidae & + & + & + & + & 2 \\
Pholadidae & + & + & - & - & 1 \\
Pinnidae & - & + & + & - & 1 \\
Psammobiidae & + & - & + & + & 1 \\
Scrobiculariidae & - & - & + & + & 1 \\
Solecurtidae & + & + & + & - & 1 \\
Solenidae & + & + & + & + & 3 \\
Spondylidae & - & - & + & - & 1 \\
Tellinidae & ++ & +++ & + & ++ & 3 \\
Veneridae & ++++ & ++++ & ++ & ++++ & 6 \\
\hline & & & & &
\end{tabular}

While other families, like Spondylidae, are specific in the Nador sector, where Glycymeridae are dominant, they influence other families such as: Donacidae and Veneridae. This sector is characterized by the presence of rare species such as the sea date Lithophaga lithophaga (Linné 1758), and the big shells give lustre to the lagoon of Nador Pina nobilis (Linné 1758).

This last species is one of the biggest shells existing in the world. Its size can exceed one meter in the lagoon of Nador. It lives in the sandy muddy depths and in the herbariums of Posidonie, buried half in the sediment and hung collided on stones by its byssus. Today, this shell has become rare and fragile.

At the level of the mouth of Moulouya, we notice an inhibition of growth of the bivalve species over 100 meters both right and left of the estuary banks. We attribute this fact to the offshore evacuation of the polluting wastes of the aquacultural company of Moulouya, which could be responsible for the disappearance of the fields of clams Chamelea gallina (Linné 1758) in this zone. Other species are strongly exploited which represent a real threat to their deposits, for instance Donax trunculus (Linné 1758).

\section{Conclusion}

Some species represent a real wealth in terms of malacological biodiversity and enjoy an important economic and biological importance, but are strongly exploited, which represents a real threat to their field. 
La connaissance de la Mer :

un vecteur du développement durable en Méditerranée

The threats which weigh on the biodiversity were identified as follows:

- Degradation and loss of the ecological balance of the marine ecosystem.

- Overexploitation of natural resources due to the lack of organization and rising awareness of fishermen.

- Lack of valorisation to the endemic species. And dilapidated and unsuitable legal arsenal for the protection of the species and the ecosystems, which complicates the protection of this heritage of the marine animal-life.

- Disturbance of malacological housing environments by the recent tourist developments of the coast.

A cooperation strengthened on an international and regional scale is necessary for the rational exploitation of bivalves, and a particular attention should be given to the preservation of the marine biodiversity, the column of water and sea bed beyond the national jurisdictions as well as the biodiversity of the deep sea bed (LLORIS \& RUCABADO, 2004).

\section{References}

CLANZID S. (1989). Evolution des peuplements malacologiques de la lagune méditerranéenne de Nador (Maroc). Vie et Milieu, 39 (2), pp 71-76.

EL BEKKAYE K., MELHAOUI M. (2010). Contribution à la connaissance de la faune malacologique des bivalves du littoral méditerranéen du Maroc. Portail Almediam.org [URL http://www.almediam.org/PDF/CONTRIBUTION_CONNAISSANCE_FAUNE_MALACOLOGIQUE_BIVALVES_LITTORAL_MEDITERANEEN_MAROC.pdf ] FOUCAULT A., RAOULT J.F. (2005). Dictionnaire de Géologie. $6^{\text {ème }}$ édition, Dunod, Liège.

IRZI Z. (2002). Les environnements du littoral méditerranéen du Maroc compris entre l'Oued Kiss et le Cap des Trois Fourches. Thèse doc. d'état., Fac. Sci. Rabat, 291 p.

LAOUINA A. (2006). Le littoral marocain, milieux côtier et marin. 190 p.

LLORIS D., RUCABADO J (1998). Guide d'identification des ressources marines vivantes du Maroc. FAO: Food and Agriculture Organization, 263 p.

LLORIS D., RUCABADO J. (2004). Biodiversité marine et côtière. COE, UNEP Council of Europe, United Nations Environnement Programme-"Biodiversité en Europe", 19-21 janvier 2004, Madrid.

MATEE -Ministère de l'Aménagement du Territoire, de l'Eau et de l'Environnement du Maroc- (1999). Biodiversité et milieu naturel - Rapport sur l'état de l'environnement du Maroc. 162 p. - (2006). Audit intégral du littoral marocain. INEA-TEC, 6 p. SAUBADE A.-M. (1979). La malacofaune actuelle (Bivalves et Gastéropodes) de la lagune de Nador (côte méditerranéenne du Maroc). Bull. Institut de Géologie du Bassin Aquitain, $\mathrm{n}^{\circ}$ 26, pp 69-90.

SHAFEE M.S. (1999). Pêche des bivalves sur la côte Méditerranéenne Marocaine, catalogue d'espèces exploitées et d'engins utilisés. IAV Hassan II, pour la FAOCOPEMED, Alicante, Espagne, 37 p. 